\title{
ULTRASONIC CAVITATION IN WASTEWATER TREATMENT FROM AZO DYE METHYL ORANGE
}

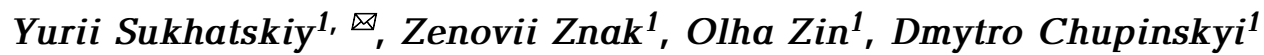

https://doi.org/10.23939/chcht15.02.284

\begin{abstract}
The work is devoted to the study of reagent treatment of methyl orange mono azo dye under the action of acoustic vibrations of the ultrasonic range. The positive effect of cavitation phenomena on the rate of mineralization of azo dye (13.4\% increase) was compared with the reagent treatment of the solution without ultrasonic vibrations. On the basis of the analyzed information sources and experimental results, a schematic technological scheme of cavitation-reagent mineralization of methyl orange was developed, the main apparatus of which is a hydrodynamic jet cavitator (scaling for industry).
\end{abstract}

Keywords: ultrasonic cavitation, azo dye, methyl orange, Fenton's reagent, hypochromic effect, mineralization, Bjerknes forces.

\section{Introduction}

Dyes are an integral component of wastewater from the printing and dyeing industries, textile, food and processing industries, since about $15 \mathrm{wt} \%$ of dye is lost during technological dyeing operations $[1,2]$. Among more than 100,000 dyes, more than $50 \%$ are azo dyes, which are mostly synthetic compounds. Today, azo dyes are widely used for dyeing all types of fibers and fabrics (cotton, wool, synthetic fibers, leather, silk), for coloring rubber and plastics, for the preparation of varnishes, printing inks, and also in the food industry. Azo dyes are characterized by the presence in their molecule of one or more azo groups $-\mathrm{N}=\mathrm{N}-$, consisting of two nitrogen atoms connected by a double bond. The azo group can be between different radicals, first of all, aromatic ones. Complex azo dyes contain several azo groups. Azo dyes are water-soluble compounds, which are difficult to biodegrade and can therefore be harmful to aquatic ecosystems. In addition, they can pose a potential

\footnotetext{
${ }^{1}$ Lviv Polytechnic National University,

12 S.Bandery St., Lviv 79013, Ukraine

sukhatsky@i.ua

(C) Sukhatskiy Yu., Znak Z., Zin O., Chupinskyi D., 2021
}

carcinogenic risk to humans. Therefore, the search for new methods and technologies for wastewater treatment from azo dyes is extremely important, especially for the countries with fast-growing industries and agriculture (India, China), that is, the problem has become worldwide.

To remove dyes in general and azo dyes in particular from wastewater, different methods are used: physical (sorption on activated carbon or other sorbents, ion exchange, membrane filtration, irradiation, foam separation), chemical (usage of oxidizing reagents hydrogen peroxide, Fenton's reagent, ozone, sodium hypochlorite, as well as macrocyclic molecules and polymers, for example, cucurbituril; photochemical combination of ultraviolet radiation and oxidants; electrochemical degradation) and biological methods (e.g., adsorption of living or dead biomass) [3]. The main advantages of physical and chemical methods are their high efficiency and simplicity of hardware design, and the disadvantage is the high cost. The main disadvantages of biological purification methods are the long duration of the process and the low ability (low potential) to mineralize the organic compounds of complex structure. Therefore, in industrial conditions, mainly chemical and physical methods are used. The most effective and currently known methods of wastewater treatment from azo dyes are chemical oxidation processes, in particular advanced oxidation processes. Traditionally, hybrid technologies based on the combination of cavitation (ultrasonic or hydrodynamic) with reagent treatment are used.

Methyl orange is a typical representative of the mono-dyes used in printing mills, as well as in the textile industry for dyeing cotton, nylon and silk. On the basis of experimental studies it was found that the maximum degree of cavitation decomposition of methyl orange, which amounted to $90.5 \%$, was reached at the hydrodynamic cavitator inlet pressure of $0.4 \mathrm{MPa}$, the reaction system temperature of $308 \mathrm{~K}$, the oxidizer (chlorine(IV) oxide) concentration of $8 \mathrm{mg} / \mathrm{dm}^{3}$ and a treatment time of $5400 \mathrm{~s}[4,5]$.

The enormous prospect of wastewater treatment from azo dyes is the combined use of hydrodynamic 
cavitation and Fenton's reagent. Generated in situ hydroxyl radicals play a major role in the processes of decomposition, oxidation, mineralization of azo dyes [6, 7]. It has been found that complete bleaching of wastewater containing methyl orange was achieved when it was treated in a hydrodynamic cavitator for $300 \mathrm{~s}$. The working pressure at the cavitator inlet was $0.6 \mathrm{MPa}$, the $\mathrm{pH}$ value of the medium was 3.0. The initial concentrations of the reagents were the following $\left(\mathrm{mol} / \mathrm{dm}^{3}\right)$ : methyl orange $3.0 \cdot 10^{-5}$; peroxide hydrogen $14.3 \cdot 10^{-5}$; $\mathrm{Fe}^{2+}$ ions $8.9 \cdot 10^{-5}$ $[8,9]$.

The combination of hydrodynamic cavitation and Fenton's reagent is also effective for bleaching wastewater containing other azo dyes. Thus, the decolorization efficiency of orange $\mathrm{G}$ is influenced by such parameters as the cavitator inlet pressure, the initial azo dye concentration, the consumption of $\mathrm{H}_{2} \mathrm{O}_{2}$, the iron concentration, its fixed location and the medium $\mathrm{pH}$. The optimal consumption of peroxide hydrogen was determined to be $0.02 \mathrm{~kg} / \mathrm{m}^{3}$; the degree of discoloration of the orange solution $\mathrm{G}$ in such a case was $93.7 \%$. Other operating parameters of orange $\mathrm{G}$ discoloration were also optimized: cavitator inlet pressure $(0.49 \mathrm{MPa}), \mathrm{pH}$ range $(2-3)$, orange $\mathrm{G}\left(0.01 \mathrm{~kg} / \mathrm{m}^{3}\right)$ and iron $\left(0.7 \mathrm{~kg} / \mathrm{m}^{3}\right)$ concentrations [10].

Synergistic coefficients for hybrid purification processes (hydrodynamic cavitation + hydrogen peroxide; hydrodynamic cavitation + Fenton's reagent; hydrodynamic cavitation + photo-Fenton; hydrodynamic cavitation + photolysis; hydrodynamic cavitation + photocatalysis) of the wastewater from the dyes mixture (methylene blue + methyl orange + rhodamine B) were equal to $28.970,6.285,4.923,1.801,2.110$, respectively [11]. Full discoloration (100\% discoloration) of the dye mixture was achieved by using a combination of hydrodynamic cavitation and reagent treatment (hydrogen peroxide) for treatment time of $2400 \mathrm{~s}$ and a molar ratio of contaminant (dye mixture): $\mathrm{H}_{2} \mathrm{O}_{2}=1: 40$. The anatase form of nanosized $\mathrm{TiO}_{2}$ was used as the nanophotocatalyst.

For the effective destruction of some azo dyes in aqueous solution, a new combined method is proposed (combining cavitation with air bubbling and adding to a solution of $\mathrm{Fe}$ (II) ions). Due to the application of this method the $76.32 \%$ degree of Congo red destruction was achieved. The experimental conditions were as follows: initial concentration of Congo red $0.01 \mathrm{~kg} / \mathrm{m}^{3}$; temperature $298 \mathrm{~K}$; duration of air bubbling $7200 \mathrm{~s}$; air flow rate $7.5 \cdot 10^{-5} \mathrm{~m}^{3} / \mathrm{s}$; diameter of a glass ball $3 \mathrm{~mm}$; consumption of $\mathrm{FeSO}_{4} \quad 0.3 \mathrm{~kg} / \mathrm{m}^{3}$ [12]. The destruction process is described by the first-order kinetic reaction equation. It was found that the degradation efficiency decreased in a row: Congo red $>$ methyl violet $>$ rhodamine $\mathrm{B}>$ methyl orange; so the dyes with unstable structure (in particular, Congo red) were easier degraded than the dyes with stable structure.

There is a growing trend in the world to use nanoparticles of metals (e.g. $\mathrm{Fe}, \mathrm{Ni}, \mathrm{Cu})[1,13,2]$ and modified natural materials (e.g. magnetite) [14] for the treatment of wastewater from azo dyes both alone and in combination with hydrodynamic cavitation.

Photocatalysis is also a promising technology for the wastewater treatment from toxic components (including azo dyes), which are difficult to be decomposed by microorganisms [15]. Typically, $\mathrm{TiO}_{2}$ nanoparticles are used as the photocatalyst.

The photodegradation of methyl orange under the action of ultraviolet radiation was carried out in aqueous suspension of mesoporous $\mathrm{TiO}_{2}\left(\mathrm{~m}-\mathrm{TiO}_{2}\right)$ nanoparticles. It was found that the illumination of an aqueous suspension containing methyl orange $\left(0.1 \mathrm{~kg} / \mathrm{m}^{3}\right)$ and $\mathrm{m}-\mathrm{TiO}_{2}$ $\left(1 \mathrm{~kg} / \mathrm{m}^{3}\right)$ for $2700 \mathrm{~s}$ with a $250 \mathrm{~W}$ mercury lamp $\left(\lambda_{\max }=\right.$ $=365 \mathrm{~nm}$ ) with light with a flow of $8.81 \mathrm{~mW} / \mathrm{cm}^{2}$ it was possible to achieve a methyl orange degree of $98 \%$. The average particle size of $\mathrm{m}-\mathrm{TiO}_{2}$ was $\sim 17.6 \mathrm{~nm}$, the crystallite size was $\sim 3.1 \mathrm{~nm}$, the specific surface area was $3.175 \cdot 10^{5} \mathrm{~m}^{2} / \mathrm{g}[16]$.

The decomposition rate constant of methyl orange on $\mathrm{TiO}_{2}$ composite films, which is surface-doped with iron, is more than 1.5 times higher than that of a bulk doped photocatalyst. The optimum $\mathrm{Fe} / \mathrm{Ti}$ ratio in the photocatalyst is $1.5 \%$ in the case of surface doping and $0.12 \%$ in the case of volumetric. In the presence of $\mathrm{H}_{2} \mathrm{O}_{2}$, the degree of decomposition of reactive dyes on $\mathrm{TiO}_{2}$ increases by more than 4 times, compared with the implementation of the process in the absence of oxidant [17].

The activity of $\mathrm{TiO}_{2}$ significantly increases upon its grafting and subsequent crystallization on the surface of silica gel particles, which simultaneously performs the functions of the carrier and dispersant of the photocatalyst. In the decomposition reactions of azo dyes (reactive 15 and cationic blue X-GRL), with the $\mathrm{TiO}_{2} / \mathrm{SiO}_{2}$ weight ratio of 3:7 the photocatalyst achieved a 3-fold photocatalytic effect on pure $\mathrm{TiO}_{2}$ [18].

The above studies are aimed primarily at the study of the hybrid processes of azo dyes degradation based on cavitation phenomena generated in hydrodynamic cavitators. Moreover, cavitation by ultrasonic generators is sufficient for local needs and water treatment equipment with low productivity. Therefore, the purpose of this work was to study the reagent mineralization of mono-dye methyl orange under the action of acoustic vibrations of the ultrasonic range. 
To achieve this goal it was necessary to solve the following tasks:

1. To analyze the changes in UV-Vis spectra of an aqueous solution containing methyl orange and Fenton's reagent, and an aqueous solution containing only Fenton's reagent during their cavitation treatment;

2. To investigate the changes in the concentration of methyl orange in its aqueous solution over time depending on the treatment mode (reagent treatment or compatible cavitation-reagent treatment) and its energy characteristics (in particular, the magnitude of the specific power of ultrasonic radiation);

3. To determine the rational energy regime of the cavitation treatment of the reaction system;

4. To calculate the rate constant of cavitationreagent mineralization of methyl orange and evaluate the technological efficiency of this process by the magnitude of the mineralization degree and the treatment duration required to achieve the maximum value of the mineralization degree;

5. To offer the basic technological scheme for cavitation-reagent mineralization of methyl orange.

\section{Experimental}

The object of the study was an aqueous solution of synthetic azo dye methyl orange (MO, Sigma-Aldrich, USA) with MO concentration of $3.06 \cdot 10^{-2} \mathrm{~mol} / \mathrm{m}^{3}$ ( $\mathrm{pH}$ of the medium is 4.0). During the studies, a peroxide hydrogen aqueous solution (35\%) of PA grade (SigmaAldrich, USA) and ferric(II) salt hydrate - ferrous sulfate (Sigma-Aldrich, USA) were used to carry out the Fenton process. The MO: $\mathrm{H}_{2} \mathrm{O}_{2}\left(35 \%\right.$ aq. solution): $\mathrm{Fe}^{2+}$ ratio was 1.0:17.5:0.6 (w/w/w).

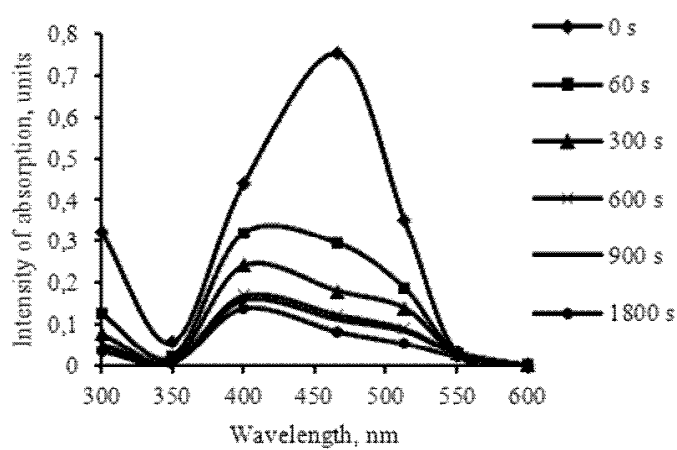

Fig. 1. UV-Vis spectra of an aqueous solution of methyl orange $\left(C_{0}=3.06 \cdot 10^{-2} \mathrm{~mol} / \mathrm{m}^{3}\right)$ and Fenton's reagent at different times of cavitation treatment; specific power of ultrasonic radiation is $68 \mathrm{~W} / \mathrm{dm}^{3}$
Ultrasonic (US) emitter of magnetostrictive type "Ultrasonic Disintegrator" UD-20 was used to generate cavitation phenomena. The specific power of ultrasonic radiation was varied in the range of $53.3-83.3 \mathrm{~W} / \mathrm{dm}^{3}$. The frequency of ultrasonic vibrations was $22 \mathrm{kHz}$. The process isotherm (temperature $298 \mathrm{~K}$ ) was provided with an UTU-4 ultra thermostat. The duration of cavitation treatment was $1800 \mathrm{~s}$.

The analysis of wastewater imitation samples was performed by UV/Vis spectroscopy on a SPECORD M40 Carl Zeiss JENA two-beam spectrophotometer using a quartz cell of $10 \mathrm{~mm}$ thickness in the wavelength range of $300-600 \mathrm{~nm}$ (MO maximal absorption at $\lambda=466 \mathrm{~nm}$ ).

In order to eliminate the undesirable effect of $\mathrm{Fe}^{3+}$ ions, they were precipitated before spectrophotometric investigations (separated from $\mathrm{Fe}(\mathrm{OH})_{3}$ solutions and filtered by a blue ribbon filter with a pore diameter of 3 $5 \mu \mathrm{m})$. Sodium hydroxide was dosed to adjust $\mathrm{pH} \approx 8$ and precipitate $\mathrm{Fe}^{3+}$ ions into solutions.

The rate constant of the degradation process of azo dye MO was determined by the method of graphical differentiation.

The degree of MO mineralization $(x, \%)$ in its aqueous solution was determined by the formula:

$$
x=100 \cdot\left(C_{0}-C\right) / C_{0}
$$

where $C_{0}$ is the initial concentration of $\mathrm{MO}$ in its aqueous solution, $\mathrm{mol} / \mathrm{m}^{3} ; C$ is the concentration of $\mathrm{MO}$ at time $\tau$, $\mathrm{mol} / \mathrm{m}^{3}$.

\section{Results and Discussion}

The UV-Vis spectra of an aqueous solution of MO and Fenton's reagent at different times of cavitation treatment are shown in Fig. 1. Fig. 2 shows the UV-Vis spectra of an aqueous solution of Fenton's reagent only, at different times of cavitation treatment.

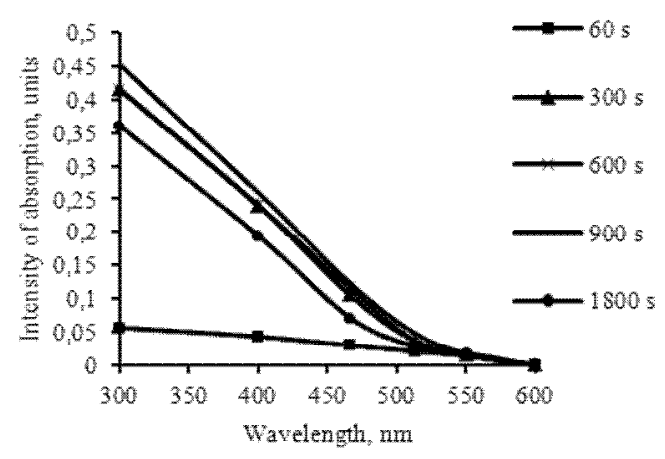

Fig. 2. UV-Vis spectra of an aqueous solution of Fenton's reagent at different times of cavitation treatment; specific power of ultrasonic radiation is $68 \mathrm{~W} / \mathrm{dm}^{3}$ 
Fig. 3. The dependence of the concentration of methyl orange in its aqueous solution on time under reagent treatment without the action of ultrasonic vibrations (1) and cavitationreagent treatment $(2,3,4)$. The specific power ultrasound radiation, $\mathrm{W} / \mathrm{dm}^{3}: 53.3(2) ; 68.03(3)$ and 83.3 (4)

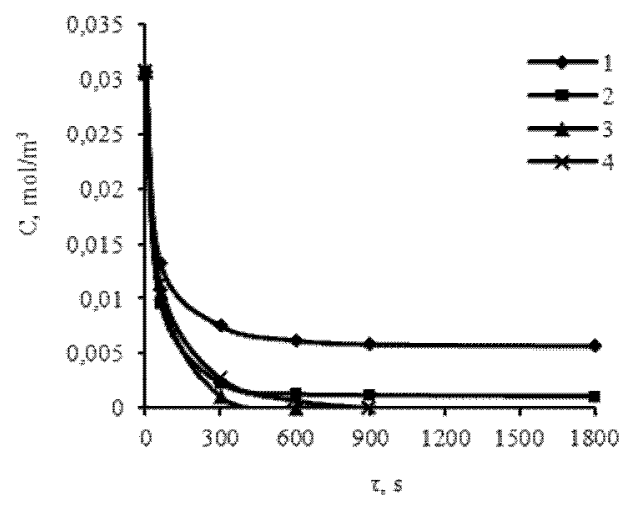

The hypochromic effect (decrease in absorption intensity) at a wavelength of $466 \mathrm{~nm}$ was established, which corresponds to the maximum absorption (peak) for MO in its aqueous solution (Fig. 1), and the hyperchromic effect (generally a monotonic increase in the absorption intensity) of an aqueous solution of Fenton's reagent (Fig. 2) at the same wavelength. In this case, bathochromic (a peak shifts to the region of higher wavelengths, i.e. waves with lower frequency and lower oscillation energy) and hypsochromic (a peak shifts to the wavelength of lower length, i.e. waves with higher frequency and greater frequency oscillations) shifts were not recorded. The above indicate the mineralization of azo dye $\mathrm{MO}$, which is described by a hypothetical (total) stoichiometric equation of reaction [8]:

$$
\begin{gathered}
\mathrm{C}_{14} \mathrm{H}_{14} \mathrm{~N}_{3} \mathrm{SO}_{3} \mathrm{Na}+19 \mathrm{H}_{2} \mathrm{O}_{2} \rightarrow \\
\rightarrow 14 \mathrm{CO}_{2} \uparrow+\mathrm{SO}_{4}{ }^{2-}+3 \mathrm{NO}_{3}{ }^{-}+\mathrm{Na}^{+}+52 \mathrm{H}^{+}
\end{gathered}
$$

The dependence of $\mathrm{MO}$ concentration $\left(C, \mathrm{~mol} / \mathrm{m}^{3}\right)$ in its aqueous solution on time $(\tau, \mathrm{s})$ under different modes of treatment and different specific power of ultrasonic radiation is shown in Fig. 3. Based on the data shown in Fig. 3, the degree of MO mineralization was calculated and graphical dependences of the $\mathrm{MO}$ mineralization rate on its concentration $\lg w=f(\lg C)$ in logarithmic coordinates were constructed. The application of the graphical differentiation method made it possible to determine the rate constants of MO mineralization.

The results obtained are summarized in the Table.

The Table shows that the imposition of cavitation fields (specific power of ultrasound radiation is $53.3 \mathrm{~W} / \mathrm{dm}^{3}$ ) on the reaction system (aqueous MO solution and Fenton's reagent) caused the increase in $\mathrm{MO}$ oxidation rate by $13.4 \%$ (from $4.79 \cdot 10^{-6}$ to $5.43 \cdot 10^{-6} \mathrm{~mol} /\left(\mathrm{m}^{3} \cdot \mathrm{s}\right)$ ), compared to the reagent treatment without ultrasonic vibrations. The degree of mineralization of the dye increases by $15 \%$ for the same treatment time, which was $1800 \mathrm{~s}$.

An increase in the specific power of the ultrasonic radiation from 53.3 to $68.0 \mathrm{~W} / \mathrm{dm}^{3}$ resulted in the increase of the oxidation rate constant by almost 2 times, and the degree of MO mineralization by $2 \%$, while the treatment duration decreases by 6 times (from 1800 to $300 \mathrm{~s}$ ).

A further increase in the specific power of the US radiation from 68.0 to $83.3 \mathrm{~W} / \mathrm{dm}^{3}$ caused a significant decrease in the rate of mineralization rate of the azo dye (2.1 times - from $10^{-5}$ to $4.81 \cdot 10^{-6} \mathrm{~mol} /\left(\mathrm{m}^{3} \cdot \mathrm{s}\right)$ ) and its degree of mineralization (by $0.7 \%$ - from 98.4 to $97.7 \%$ ) by increasing the duration of ultrasonic vibrations by 2 times (from 300 to $600 \mathrm{~s}$ ).

Table

Kinetic characteristics and technological efficiency of processes

\begin{tabular}{|c|c|c|c|c|}
\hline \multirow{4}{*}{ Indication } & \multicolumn{4}{|c|}{ Method of processing } \\
\hline & \multirow{3}{*}{$\begin{array}{l}\text { Reagent } \\
\text { treatment }\end{array}$} & \multicolumn{3}{|c|}{ Cavitation-reagent mineralization } \\
\hline & & \multicolumn{3}{|c|}{ Specific power of cavitation processing, W/dm 3} \\
\hline & & 53.3 & 68.0 & 83.3 \\
\hline $\begin{array}{l}\text { Velocity constant, } \mathrm{k} \cdot 10^{6}, \\
\mathrm{~mol} /\left(\mathrm{m}^{3} \cdot \mathrm{s}\right)\end{array}$ & 4.79 & 5.43 & 10.00 & 4.81 \\
\hline $\begin{array}{l}\text { The degree of mineralization, } \\
\% \text { (duration of treatment, } s \text { ) }\end{array}$ & $\begin{array}{c}81.4 \\
(1800)\end{array}$ & $\begin{array}{c}96.4 \\
(1800)\end{array}$ & $\begin{array}{c}98.4 \\
(300)\end{array}$ & $\begin{array}{l}97.7 \\
(600)\end{array}$ \\
\hline
\end{tabular}
of reagent treatment and cavitation-reagent mineralization of methyl orange 
Probably, this can be explained by the coalescence (union) of cavitation bubbles under the action of Bjerknes forces. Bjerknes forces are electrostatic attraction forces that arise between spherical-shaped air bubbles in a liquid [19]. The time-averaged interaction force $(F, \mathrm{~N})$ between two spherical bubbles, which are pulsating in a liquid, by Bjerknes is [19]:

$$
F=\frac{\rho \Omega_{1} \Omega_{2} \cos \psi}{4 \pi l^{2}}
$$

where $\rho$ is the density of the liquid, $\mathrm{kg} / \mathrm{m}^{3} ; \Omega=4 \pi R_{b}^{2} w$ is the volumetric rate of the pulsating bubble, $\mathrm{m}^{3} / \mathrm{s} ; \psi$ is the phase difference of vibrations of spherical bubbles; $l$ is the distance between the bubbles, $\mathrm{m} ; R_{b}$ is the bubble radius, $\mathrm{m}$.

As the concentration of bubbles per unit volume in the reaction system increases with the increase in the specific power of the ultrasonic radiation, it is natural that the distance between them decreases. According to Eq. (3), this leads to the increase in the Bjerknes force and, in turn, to the coalescence of bubbles, and, consequently, to the decrease in the intensity of the cavitation phenomena. The weakening of cavitation leads to the decrease in the concentration of particles of a radical nature in the environment and, as a consequence, the degree of mineralization and a significant slowdown of this process.

Therefore, there is a rational value of the specific power of the ultrasound radiation for the reaction system (aqueous MO solution and Fenton's reagent), which is about $68 \mathrm{~W} / \mathrm{dm}^{3}$.

For deep treatment from $\mathrm{MO}$ at its excessive concentrations in wastewater of printing and dye industries, as well as textile enterprises, a combination of cavitation-reagent treatment and sorption using natural sorbents (zeolites) after their previous thermal activation has been proposed. Since zeolites have ion-exchange properties, they can remove $\mathrm{Fe}^{3+}$ ions presented in solution due to the implementation of the Fenton process. It is not advisable to recover the spent zeolites; they can be used for the production of cement, building materials and various fillers.

On the basis of the analysis of literature data and the results of the performed researches, a technological scheme of MO cavitation-reagent mineralization process (Fig. 4) was developed, which consists of four main parts: 1) block of averaging and preliminary purification of wastewater from coarse particulate solids; 2) a block of reagents preparation (aqueous solutions of hydrogen peroxide and iron sulfate); 3) a block of MO cavitation mineralization; 4) a block of deep sorption of residual MO and $\mathrm{Fe}^{3+}$ ions.

The wastewater of printing and dye industries by circulating pumps 1 is fed into a tank-aerator 2 , in which an averaging of different qualitative and quantitative composition of wastewater pollutants takes place. The averaged wastewater is supplied to a single-stage filter separator 3, which is used for pre-treatment of wastewater from coarse particulate matter.

Aqueous solutions of hydrogen peroxide and iron sulphate are fed by pumps-dispensers 7 and 8 from tanks 5 and 6 . The resulting reaction medium (aqueous MO solution and Fenton's reagent) is sent to a hydrodynamic cavitator of jet type 9 , in which cavitation mineralization occurs.

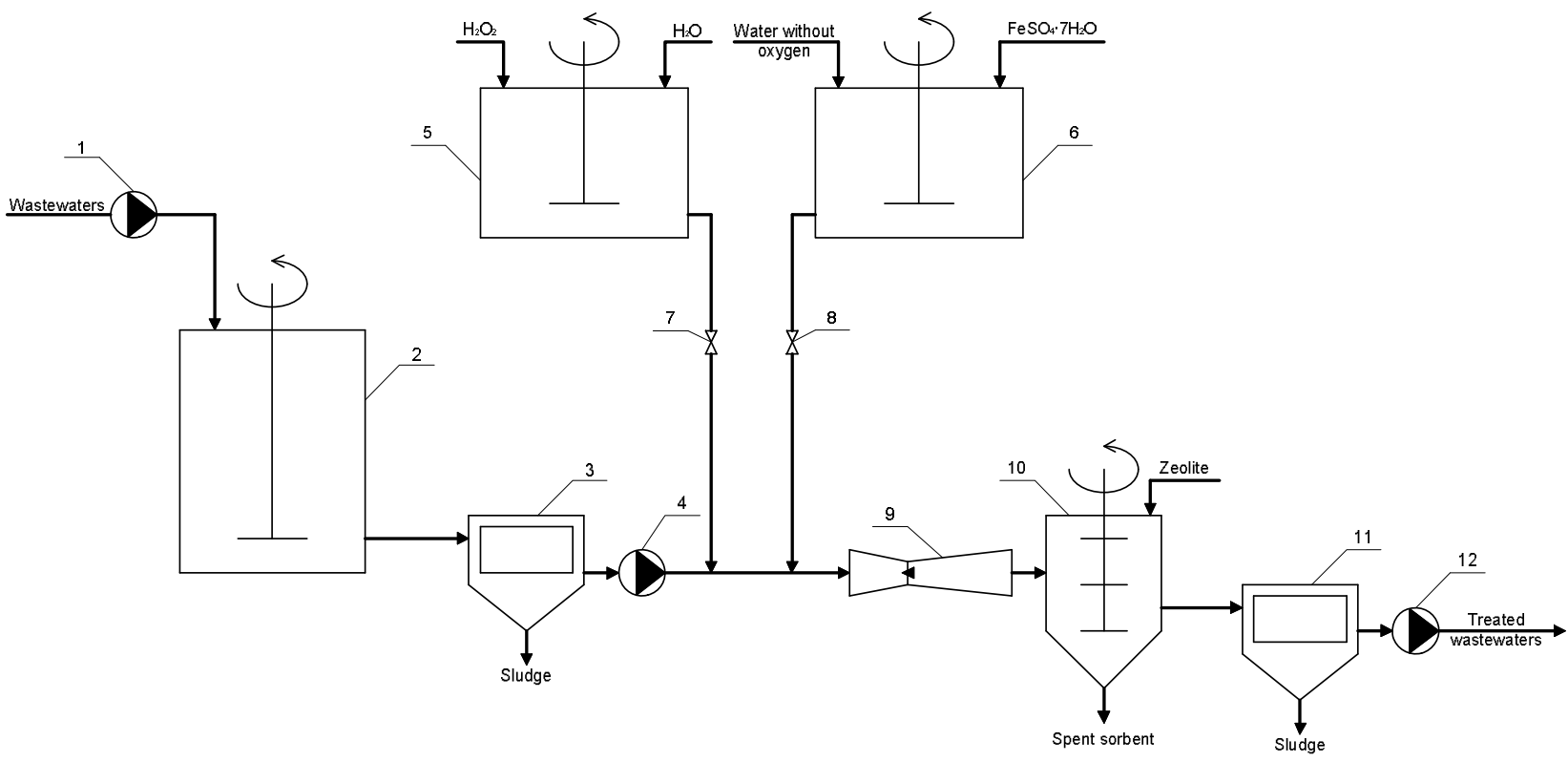

Fig. 4. Technological scheme of MO cavitation-reagent mineralization: 1, 4, 12 - circulation pumps; 2 - averaging tank; 3,11-one-stage filters-separators; 5, 6, 10-tanks with stirrers; 7, 8 - pumps-dispensers; 9 - hydrodynamic cavitator 
After cavitator 9 , the wastewater is fed to the stage of deep sorption purification from the residual content of $\mathrm{MO}$ and $\mathrm{Fe}^{3+}$ ions, which is implemented in the reactor (tank) with a stirrer 10. After sorption on zeolites, water is fed to a one-stage filter separator 11 to separate the dispersed solids. Wastewater treated to normative values by circulating pumps 12 is directed to municipal wastewater treatment plants.

The control parameters are: the level of solutions (for tanks 2, 5, 6, 10); operating pressure at the inlet of the hydrodynamic cavitator 9 (pressure is $0.40 \pm 0.05 \mathrm{MPa}$ ); consumption of aqueous solutions of $\mathrm{H}_{2} \mathrm{O}_{2}$ and $\mathrm{FeSO}_{4} \cdot 7 \mathrm{H}_{2} \mathrm{O}$.

The research results can be implemented at water treatment plants of printing and dye industries, textile, food and processing industries.

\section{Conclusions}

Research on cavitation-reagent treatment of aqueous azo dye MO solution was performed. Based on the analysis of UV-Vis spectra of an aqueous MO solution and Fenton's reagent, a hypochromic effect at a wavelength of $466 \mathrm{~nm}$ was detected, which, in the absence of bathochromic and hypochromic shifts, indicates cavitation-reagent mineralization of MO.

It was established that the generation of cavitation phenomena (specific power of ultrasound radiation is $53.3 \mathrm{~W} / \mathrm{dm}^{3}$ ) in the reaction system (aqueous MO solution and Fenton's reagent) caused the rate of mineralization of azo dye by $13.4 \%$ (from $4.79 \cdot 10^{-6}$ to $5.43 \cdot 10^{-6} \mathrm{~mol} /\left(\mathrm{m}^{3} \cdot \mathrm{s}\right)$ ), compared to the reagent treatment of the solution without the action of ultrasonic vibrations. The degree of dye mineralization increased by $15 \%$ for the same treatment time, which was $1800 \mathrm{~s}$.

An increase in the specific power of ultrasound radiation from 53.3 to $68.0 \mathrm{~W} / \mathrm{dm}^{3}$ resulted in the increase of the mineralization rate by almost 2 times, and the degree of MO mineralization - by $2 \%$, while reducing the treatment time by 6 times (from 1800 to $300 \mathrm{~s}$ ). Further increase in the specific power of the ultrasound radiation (up to $83.3 \mathrm{~W} / \mathrm{dm}^{3}$ ) caused a significant decrease in the mineralization rate of the azo dye (by 2.1 times) and the degree of mineralization (by $0.7 \%$ ) by increasing the duration of ultrasound vibrations by 2 times. This can probably be explained by the coalescence of cavitation bubbles under the action of Bjerknes forces.

According to the results of experimental studies, a rational energy regime of cavitation treatment of the reaction system (specific power of ultrasonic radiation $\sim 68 \mathrm{~W} / \mathrm{dm}^{3}$ ) containing an aqueous $\mathrm{MO}$ solution and Fenton's reagent was determined.

On the basis of literature data and experimental results, a conceptual technological scheme of cavitation- reagent mineralization of $\mathrm{MO}$ was developed, the main apparatus of which is a hydrodynamic jet cavitator (scaling for industry).

\section{Acknowledgements}

The publication contains the results of studies conducted by President's of Ukraine grant for competitive projects (project registration number F82/43168; contract F82/220-2019).

The obtained results will also be used to compare the performance of ultrasonic and hydrodynamic cavitation in the framework of a joint Ukrainian-Indian research project "Hydrodynamic cavitation based intensified and low cost technology for industrial wastewater treatment containing toxic organic compounds and solid particles" (M/88-2019 of June 26, 2019).

\section{References}

[1] Innocenzi V., Prisciandaro M., Centofanti M., Vegliò F.: J. Environ. Chem. Eng., 2019, 7, 103171.

https://doi.org/10.1016/j.jece.2019.103171

[2] Li P., Song Y., Wang S. et al.: Ultrason. Sonochem., 2015, 22,

132. https://doi.org/10.1016/j.ultsonch.2014.05.025

[3] Robinson T., McMullan G., Marchant R., Nigam P.: Bioresour.

Technol., 2001, 77, 247. https://doi.org/10.1016/S0960-

8524(00)00080-8

[4] Yang S., Jin R., He Z., et al.: Chem. Eng. Trans., 2017, 59, 289. https://doi.org/10.3303/CET1759049

[5] Yang S., Jin R., He Z., et al.: Chem. Eng. Trans., 2017, 59, 1063. https://doi.org/10.3303/CET1759178

[6] Koval I., Kislenko V., Starchevskii V., Shevchuk L.: J. Water

Chem. Technol., 2012, 34, 112.

https://doi.org/10.1016/j.cej.2010.07.063

[7] Koval I., Starchevskyy V.: Chem. Chem. Technol., 2020, 14, 264. https://doi.org/10.23939/chcht14.02.264

[8] Batoyeva A., Sizykh M., Aseyev D., Khandarkhayeva M.: Voda: Khimiya i Ekologiya, 2011, 9, 27.

[9] Batoyeva A., Sizykh M., Aseyev D.: Vestnik IrGTU, 2010, 3, 77.

[10] Cai M., Su J., Zhu Y., et al.: Ultrason. Sonochem., 2016, 28, 302. https://doi.org/10.1016/j.ultsonch.2015.08.001

[11] Suresh Kumar M., Sonawane S., Bhanvase B., Bethi B.: J. Water Process. Eng., 2018, 23, 250.

https://doi.org/10.1016/j.jwpe.2018.04.004

[12] Ma C., Zhang L., Wang J., Li S., Li Y.: Res. Chem. Intermed., 2015, 41, 6009. https://doi.org/10.1007/s11164-014-1717-3

[13] Fan J., Guo Y., Wang J., Fan M.: J. Hazard. Mater., 2009, 166, 904. https://doi.org/10.1016/j.jhazmat.2008.11.091

[14] Rahim Pouran S., Bayrami A., Abdul Aziz A. et al.: J. Mol. Liq., 2016, 222, 1076. https://doi.org/10.1016/j.molliq.2016.07.120

[15] Cui P., Chen Y., Chen G.: Ind. Eng. Chem. Res., 2011, 50, 3947. https://doi.org/10.1021/ie100832q

[16] Dai K., Chen H., Peng T., Ke D., Yi H.: Chemosphere, 2007, 69, 1361. https://doi.org/10.1016/j.chemosphere.2007.05.021

[17] Soboleva N., Nosonovich A., Goncharuk V.: Khimiya i

Tekhnologiya Vody, 2007, 29, 125.

[18] Chun H., Yizhong W., Tang H.: Appl. Catal. B, 2001, 35, 95. https://doi.org/10.1016/S0926-3373(01)00236-3 
[19] Yavorskiy V., Sukhatskiy Y., Znak Z., Mnykh R.: Chem. Chem. Technol., 2016, 10, 507.

https://doi.org/10.23939/chcht10.04.507

Received: December 15, 2019 / Revised: January 12, 2020 / Accepted: March 13, 2020

\section{УЛЬТРАЗВУКОВА КАВІТАЩІЯ В ОЧИЩЕННІ СТІЧНИХ ВОД ВІД АЗОБАРВНИКА МЕТИЛОВОГО ОРАНЖЕВОГО}

Анотація. Досліджено реатентне оброблення моноазобарвника метилового оранжевого під дією акустичних коли- вань ультразвукового діапазону. Встановлено позитивний вплив кавітачійних явищ на швидкість мінералізаиії азобарвника (зростання на 13,4\%), порівняно із реатентним обробленням розчину без дї ультразвукових коливань. На основі аналізу джерел інформаиіі та результатів виконаних досліджень розроблено принципову технологічну схему кавітаційно-реатентної мінералізаиії метилового оранжевого, основним апаратом якої $\epsilon$ гідродинамічний струменевий кавітатор (масштабування для промисловості).

Ключові слова: ультразвукова кавітачія, азобарвник, метиловий оранжевий, реактив Фентона, гіпохромний ефект, мінералізачія, сили Бьєркнеса. 